\title{
African Society of Toxinology: a new opportunity for integrating the control of envenomations in Africa
}

Chippaux JP $(1,2)$

(1) Center for the Study and Research of Malaria Associated with Pregnancy and Childhood (Cerpage), Cotonou, Benin; (2) Institute of Research for Development (IRD - UMR 216 "Mother and child facing tropical diseases"), Cotonou, Benin.

Dear Editor,

In Africa, snakebites and scorpion stings have long been oppressive for indigenous peoples, frightening for foreign travelers and confusing for medical personnel... In many tropical countries, studies were performed to assess the importance and management of envenomations. Since the $18^{\text {th }}$ century, many works have addressed Indian venomous snakes and treatment of their bites $(1,2)$. In Brazil, studies began in the late $19^{\text {th }}$ century (3). In Africa, apart from some systematic zoological studies in the early or mid $20^{\text {th }}$ century, sustained research commenced mainly after the end of the colonial era (4-8). However to date, the incidence and mortality in Africa remain poorly known, limiting the organization of management and prediction of therapeutic needs (9).

The development of research on venomous animals, venoms and envenomation truly started in North Africa in the 1960s, followed in subSaharan Africa in the early 1970s. The number of published studies increased significantly over the past decade, particularly with regard to subSaharan Africa. Considering the publications indexed in major bibliographic databases either printed (Bulletin de l'Institut Pasteur since 1903, Tropical Diseases Bulletin since 1912, Bulletin Signalétique du CNRS since 1940) or online (Pascal since 1971, Medline since 1972), the number of publications, excluding books, increased almost fivefold compared to the 1970s showing the emergence of the first African teams involved in research toxinology (Figure 1). However, publishing articles is highly dependent on congresses which are opportunities to present works completed by researchers and explain why the level of publications is so irregular from one year to the next... In addition, it should be emphasized that the clinical and epidemiological studies represent more than two thirds of published works.

Following its creation in 1975, African and Middle Eastern researchers have gradually become attached to the European section of the IST (http://www.toxinology.org/European Section.htm). However, since the 1990s, the need to develop a section specific to Africa and the Middle East has become obvious.

During the last decade, several "International Conferences on envenomation by snakebites and scorpion stings in Africa" have been held successively in Dakar (10), Cotonou in 2004 (11), Brazzaville in 2007 (12) and again in Dakar from 25 to 29 April 2011 (13). Meanwhile, the Egyptian Society of Natural Toxins organized the first international conference on natural toxins in Cairo from 16 to 18 December 2008, which has since become annual.

In this context and to coordinate these initiatives, the idea of the creation of the African Society of Toxinology (ASV), in French "Société de Venimologie" (SAV), was born. To prepare this project, in collaboration with Professor Achille Massougbodji, from Benin, and Professor 


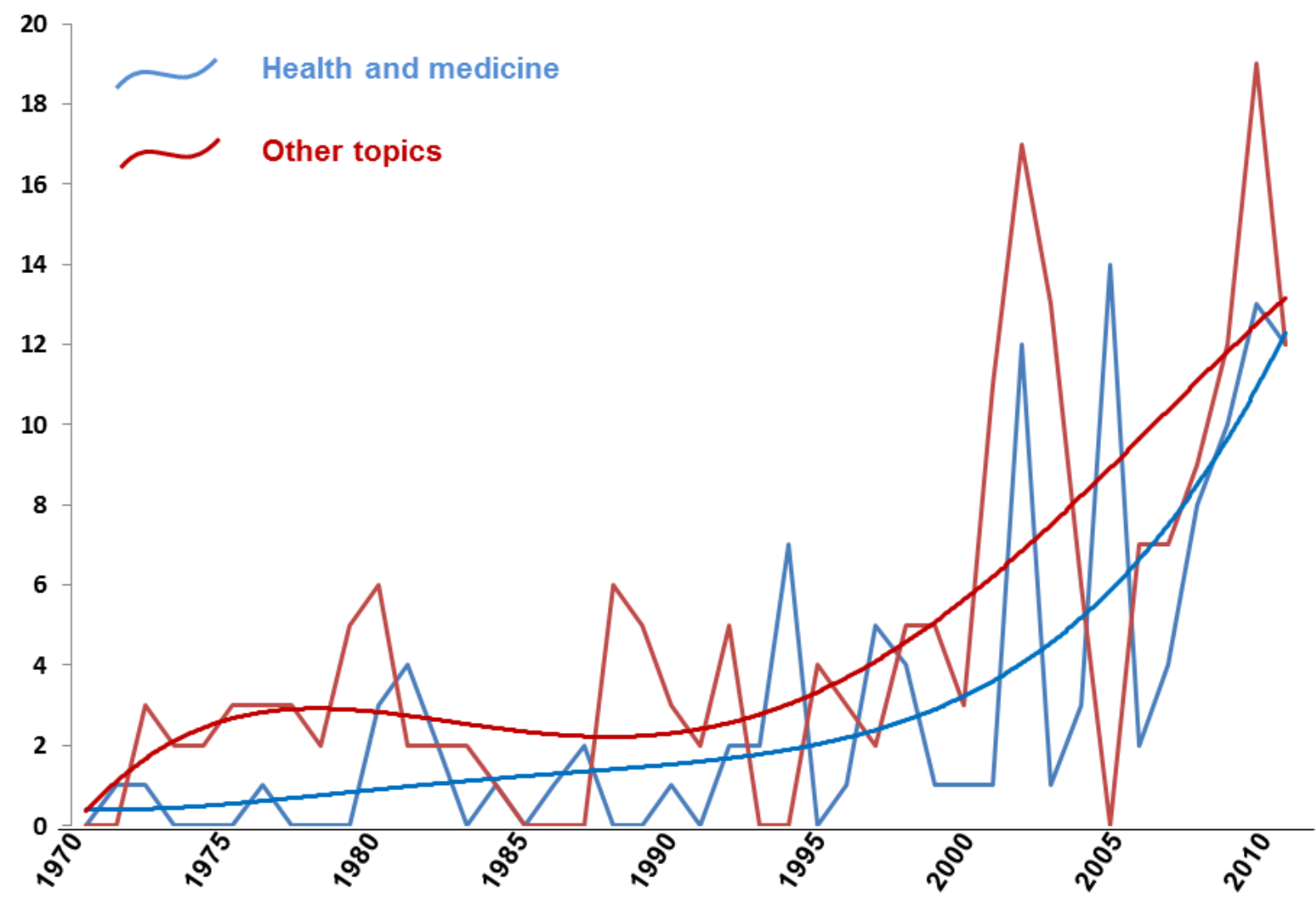

Figure 1. Trend in the number of articles on venomous animals, venoms and envenomations in Africa between 1970 and 2011.

Abdulrazaq Habib, from Nigeria, we organized a questionnaire which was sent in early 2012 to all African scientists and practitioners then known to us, to assess the needs for creating a scientific society devoted to the study of venoms and envenomations.

We obtained 63 responses from 13 African countries (and some from other continents!). A large majority of respondents $(80 \%)$ favored the creation of an African section (with colleagues from the Middle East eventually) rather than join the European section (11\%). The rest (9\%) would agree to join either of the sections. This scenario seems mainly attributable to the feeling that the concerns of the European section are divergent from the aspirations of African researchers and practitioners, particularly in regard to therapeutic and operational aspects.

Strategies and activities proposed in the framework of the future African Society of Toxinology will regard:
- Support from the society for the realization of an inventory of the epidemiological and clinical situations (45\%);

- Assistance in training ASV/SAV members (40\%);

- A commitment to international and regional mobilization in order to create national envenomation management programs $(30 \%)$;

- The institutionalization of the control of envenomations (25\%);

- Synergy between members and the sharing of experiences at regular scientific meetings $(20 \%)$;

- Support for research funding (15\%).

Finally, the questionnaire revealed a strong willingness to create an African Society of Toxinology (ASV/SAV) primarily devoted to operational studies to ensure a better knowledge of snake and scorpion envenomation and the organization of their management at a regional level. 
On the basis of these results, the Society was created on June 20,2012 by a Constituent General Assembly during the International Congress on Envenomations by Snakebites and Scorpion Stings in Cotonou, Benin.

After presentation of the history and rationale of the Society, the statutes were presented in a plenary session and adopted by a show of hands. A board was elected, representative of the linguistic and environmental diversity of Africa, and involving northern, western, central and eastern/southern Africa.

Scorpionism predominates in North Africa and the Sahara (14). It is also present in South Africa. Although long unknown in central Africa, the Kinshasa Antivenom Center team observed that the incidence and severity of scorpion stings were also important in the center of the Congolese forest, Democratic Republic of Congo, requiring extensive studies (15).

Analysis of scorpion and snake venoms began in northern Africa in the 1950s, and is continuing actively in the various countries of the Maghreb $(16,17)$, in combination with the development of experimental studies on the pharmacological action of the venom on inflammatory syndrome (18). Epidemiological studies confirm the importance and severity of scorpion stings in Algeria (19). Simultaneously, clinical and therapeutic investigations show the diversity of the pharmacological action exerted by scorpion venom on the human cardiovascular and neurological systems $(20,21)$.

Biological and ecological studies conducted in different settings in sub-Saharan Africa confirm the close relationship between ophidian behavior and bite risk (22), opening new perspectives for the epidemiology and prevention of envenomation accidents.

Presentations of clinical envenomation cases served as a reminder of the consequences, not only in relation to mortality but also disability $(21,23)$. Therapeutic uncertainties, especially for the treatment of envenomation by Elapidae are highlighted by (24).

In addition to the methodological aspects, including the collection of reliable data (25), the implications for the management of envenomation in tropical countries with low incomes are emphasized $(26,27)$.

The ASV/SAV - which already has one hundred members - aims to bring together researchers and practitioners working for a better understanding of venomous animals, venoms, and envenomations to improve their management. Its primary objective is to welcome all colleagues from French-, English-, Spanishand Portuguese-speaking Africa to rally the entire community of African scientists. Subsequently, ASV/SAV aspires to unite with those from the Middle East to establish a joint African and Middle East section of IST.

\section{COPYRIGHT \\ (C) CEVAP 2012}

\section{SUBMISSION STATUS}

Received: October 30, 2012.

Accepted: October 30, 2012.

Full paper published online: November 30, 2012.

\section{CONFLICTS OF INTEREST}

The authors declare no conflicts of interest.

\section{CORRESPONDENCE TO}

Jean-Philippe Chippaux, UMR 216, IRD, 08 BP 841, Cotonou, Bénin. Phone: +229 94345110. Email: jean-philippe.chippaux@ird.fr.

\section{REFERENCES}

1. Hawgood BJ. The life and viper of Dr Patrick Russell MD FRS (1727-1805): physician and naturalist. Toxicon. 199432(11):1295-304.

2. Hawgood BJ. Sir Joseph Fayrer MD FRS (1824-1907) Indian Medical Service: snakebite and mortality in British India. Toxicon. 1996;34(2):171-82.

3. Hawgood BJ. Pioneers of anti-venomous serotherapy: Dr Vital Brazil (1865-1950). Toxicon. 1992;30(56):573-9.

4. Fitz Simons FW. The snake of South Africa - Their venom and the treatment of snake bite. Cape Town: Maskew Miller; 1910. 160p.

5. Angel F. Les serpents de l'Afrique occidentale française. Bull Com Et Hist Scient AOF. 1932;15(4):613-858

6. Pitman CRS. A guide to the snakes of Uganda. Kampala: Uganda Society; 1938. 362p.

7. Villiers A. Les serpents de l'Ouest africain. Dakar: IFAN; 1950. 148p.

8. Vachon M. Etude sur les scorpions. Alger: Institut Pasteur; 1952. 482p.

9. Chippaux JP. Estimating the global burden of snakebite can help to improve management. PLoS Med. 2008;5:e221.

10. Chippaux JP, Goyffon M. Immunothérapie dans les envenimations: Coloque Dakar (SEN), 26 octobre 2001. Bull Soc Pathol Exot. 2001;94:366-7.

11. Chippaux JP, Alagón A, Stock R. Report of the $2^{\text {nd }}$ International Conference on Envenomations in 
Africa (Deuxième Colloque International sur les Envenimations en Afrique). Toxicon. 2005;46(1):1158.

12. Chippaux JP, Massougbodji A, Stock R, Akiana J, Mokondjimobe E, Parra HJ. Compte rendu de la $3^{\text {ème }}$ Conférence Internationale sur les Envenimations en Afrique. Bull Soc Pathol Exot. 2008;101(5):437-8.

13. Chippaux JP, Diouf A, Stock RP, Parra HJ, Massougbodji A. Report of the 4th international conference on envenomations by snakebites and scorpion stings in Africa, Dakar, April 25-29, 2011. Toxicon. 2011;58(5):426-9.

14. Goyffon M, Dabo A, Coulibaly SK, G. Togo G, Chippaux JP. Dangerous scorpion fauna of Mali. J Venom Anim Toxins incl Trop Dis. 2012;18(4):361-8.

15. Biezakala Mudiandambu E, Odio Wobin T, Kabele Ngiefu C, Tati Kinkela R, Mbanzulu Makola K. Scorpion envenomation in pygmies from Democratic Republic of Congo, the example of Pelenge Center, Lomela. J Venom Anim Toxins incl Trop Dis. 2012;18(4):451-4.

16. Chérifi F, Laraba-Djebari F. Pharmacological activity of isolated biomolecules from Viperidae venom: their role in haemostasis. J Venom Anim Toxins incl Trop Dis. Forthcoming 2013.

17. Oukkache N, Lalaoui M, Ghalim N. General characterization of the venom from the Moroccan snakes Macrovipera mauritanica and Cerastes cerastes. J Venom Anim Toxins incl Trop Dis. 2012;18(4):41120.

18. Saidi H, Adi-Bessalem S, Hammoudi-Triki D, LarabaDjebari F. Effects of atropine and propranolol on lung inflammation in experimental envenomation: comparison of two Buthidae venoms. J Venom Anim Toxins incl Trop Dis. Forthcoming 2013.
19. Laïd Y, Boutekdjiret L, Oudjehane R, Laraba-Djebari F, Hellal H, Mesbah S, et al. Incidence and severity of scorpion stings in Algeria. J Venom Anim Toxins incl Trop Dis. 2012;18(4):399-410.

20. Delma K. Echocardiographic changes during acute pulmonary edema subsequent to scorpion sting. J Venom Anim Toxins incl Trop Dis. 2012;18(4):421-6.

21. Delma K. About a case of blindness following scorpion envenomation. J Venom Anim Toxins incl Trop Dis. 2012;18(4):478-82.

22. Akani GC, Ebere N, Franco D, Eniang EA, Petrozzi F, Politano E, Luiselli L. Matching between annual activity patterns of venomous snakes and rural people in the Niger delta, southern Nigeria. J Venom Anim Toxins incl Trop Dis. Forthcoming 2013.

23. Gras S, Plantefève G, Baud F, Chippaux JP. Snakebite on the hand: lessons from two clinical cases illustrating difficulties of surgical indication. J Venom Anim Toxins incl Trop Dis. 2012;18(4):467-77.

24. Baldé MC, Chippaux JP, Boiro MY, Stock RP, Massougbodji A. Use of antivenoms for the treatment of envenomation by Elapidae in Guinea, SubSaharan Africa. J Venom Anim Toxins incl Trop Dis. Forthcoming 2013.

25. Chippaux JP. Epidemiological investigation on envenomation: from theory to practice. J Venom Anim Toxins incl Trop Dis. 2012;18(4):446-50.

26. Kyelem CG, Yaméogo TM, Ouédraogo SM, Zoungrana J, Poda GEA, Rouamba MM, et al. Snakebite in BoboDioulasso, Burkina Faso: illustration of realities and challenges for care based on a clinical case. J Venom Anim Toxins incl Trop Dis. 2012;18(4):483-5.

27. Habib AG. Public health perspectives of snakebite care in Nigeria. J Venom Anim Toxins incl Trop Dis. Forthcoming 2013. 